reconnaissant

que la seconde du Système International peut être réalisée en pratique avec une précision meilleure que 2 sur $10^{13}$,

que les distances sur Terre et dans l'espace sont mesurées par le temps de parcours de rayonnement électromagnétique, et que le Système des Constantes Astronomiques de l'UAI sera révisé dans le cours des trois années à venir, considère

qu'une valeur unique de la vitesse de propagation du rayonnement électromagnétique devrait être utilisée lorsque l'on exprime en mètres les résultats des mesures de distance les plus précises, et

recommande

que, lorsque la valeur la plus précise de la vitesse de propagation du rayonnement électromagnétique dans le vide est nécessaire, la valeur proposée par le Comité Consultatif pour la Définition du Mètre à sa réunion de juin 1973, c'est-à-dire:

soit utilisée,

$$
c=299792458 \text { mètres par seconde, }
$$

que cette valeur de la vitesse de propagation du rayonnement électromagnétique soit incorporée dans la révision prochaine du Système des Constantes Astronomiques de l'UAI, et

que le Comité International des Poids et Mesures maintienne cette valeur dans toute éventuelle définition du Mètre.

\title{
RÉSOLUTION NO. 7
}

\section{Proposée par le Comité des Résolutions}

Sur les résolutions adoptées par les Commissions

Considérant qu'il lui est pratiquement impossible d'accorder une attention particulière à chaque résolution adoptée par chacune de ses diverses Commissions et ayant une confiance entière en ses Commissions, cette Assemblée Générale désire exprimer son approbation des Résolutions adoptées par ses différentes Commissions, recommande aux astronomes de les mettre en application dans la limite de leurs possibilités, et demande au Comité Exécutif de veiller, autant que possible, à la compatibilité de ces résolutions et à leur application. 
recognizing

that the second of the Systeme International can be realized in practice with a precision of better than 2 parts in $10^{13}$,

that distances on Earth and in space are measured by times of travel of electromagnetic radiation, and

that the IAU System of Astronomical Constants will be revised within the next three years, considers

that a common value of the speed of propagation of electromagnetic radiation should be used when expressing in metres the results of the most precise measurements of distance, and recommends

that when the most precise value of the speed of propagation of electromagnetic radiation in vacuum is required, the value proposed by the Comite Consultatif pour la Définition du Mètre at their meeting in 1973 June, namely

$$
c=299792458 \text { metres per second, }
$$

should be used,

that this value of the speed of propagation of electromagnetic radiation should be incorporated in the next revision of the IAU System of Astronomical Constants, and

that the Comité International des Poids et Mesures should maintain this value in any re-definition of the metre.

RESOLUTION NO. 7

\section{Proposed by the Resolutions Committee}

On the resolutions adopted by Commissions

Considering the impracticability of giving individual attention to every resolution adopted by each of its Commissions, and having full confidence in its Commissions, this General Assembly wishes to give its endorsement to the Resolutions adopted by its individual Commissions, recommends that astronomers give effect to these Resolutions in so far as they are able, and asks the Executive Committee to insure, inasmuch as possible, the compatibility of the resolutions and to put them into effect. 